
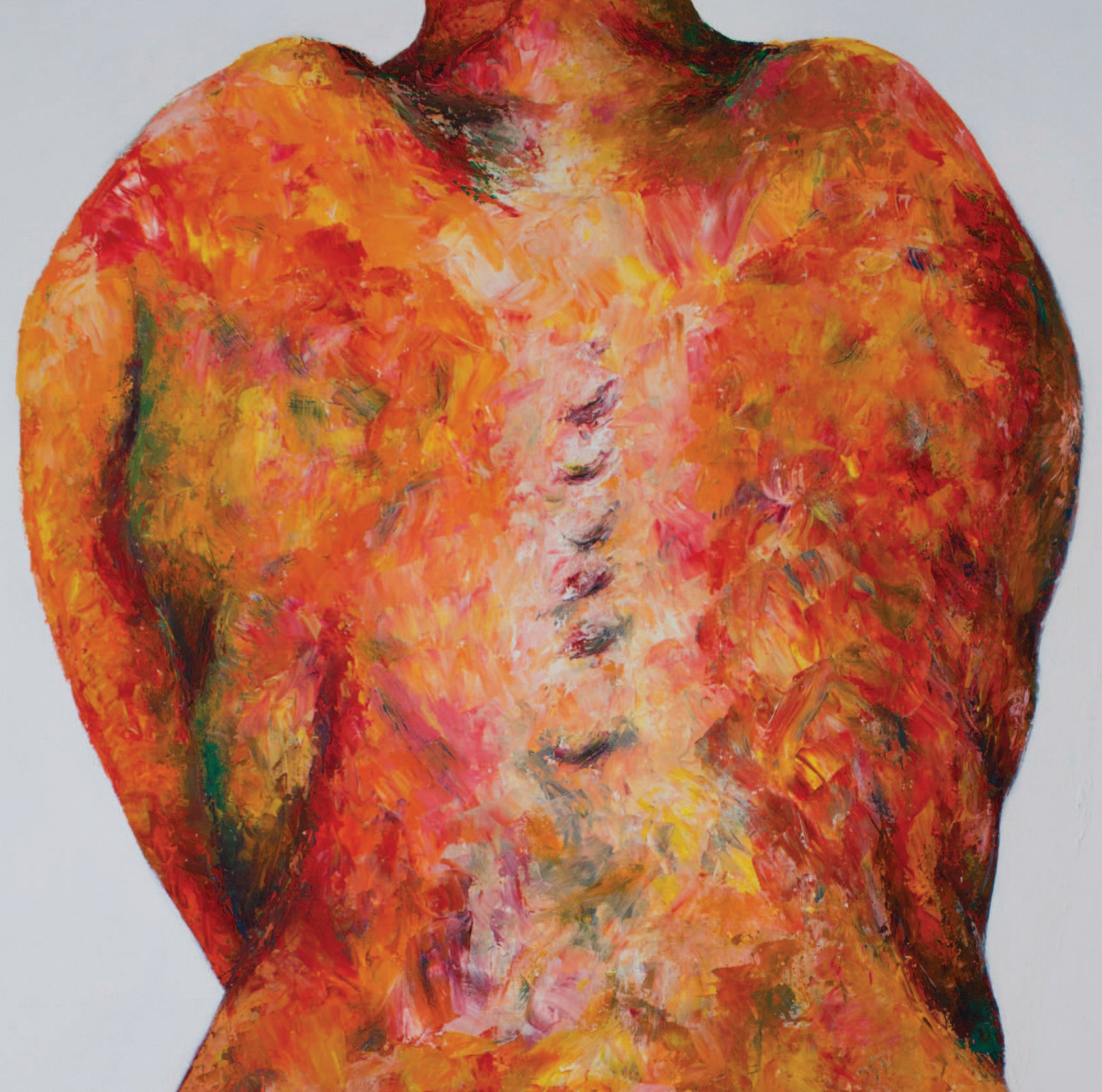

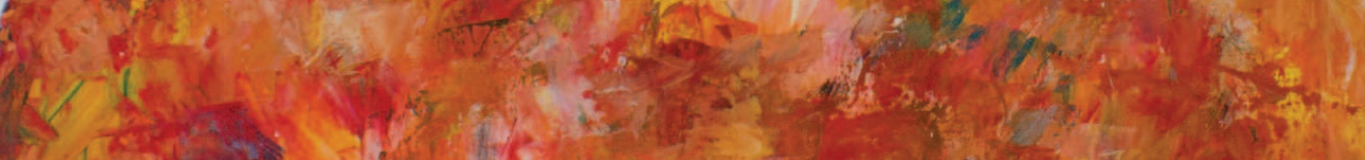

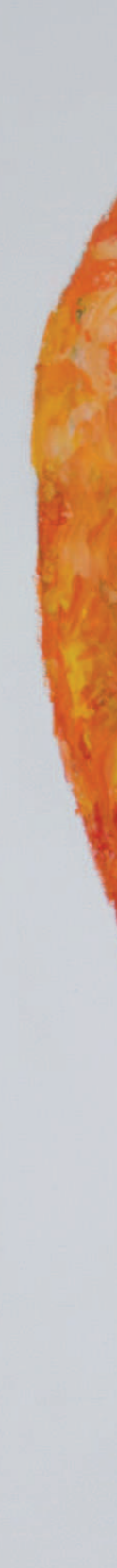

1

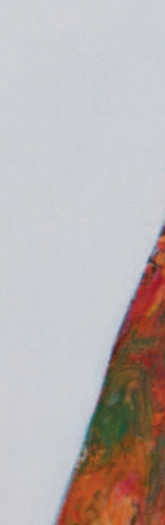

2.

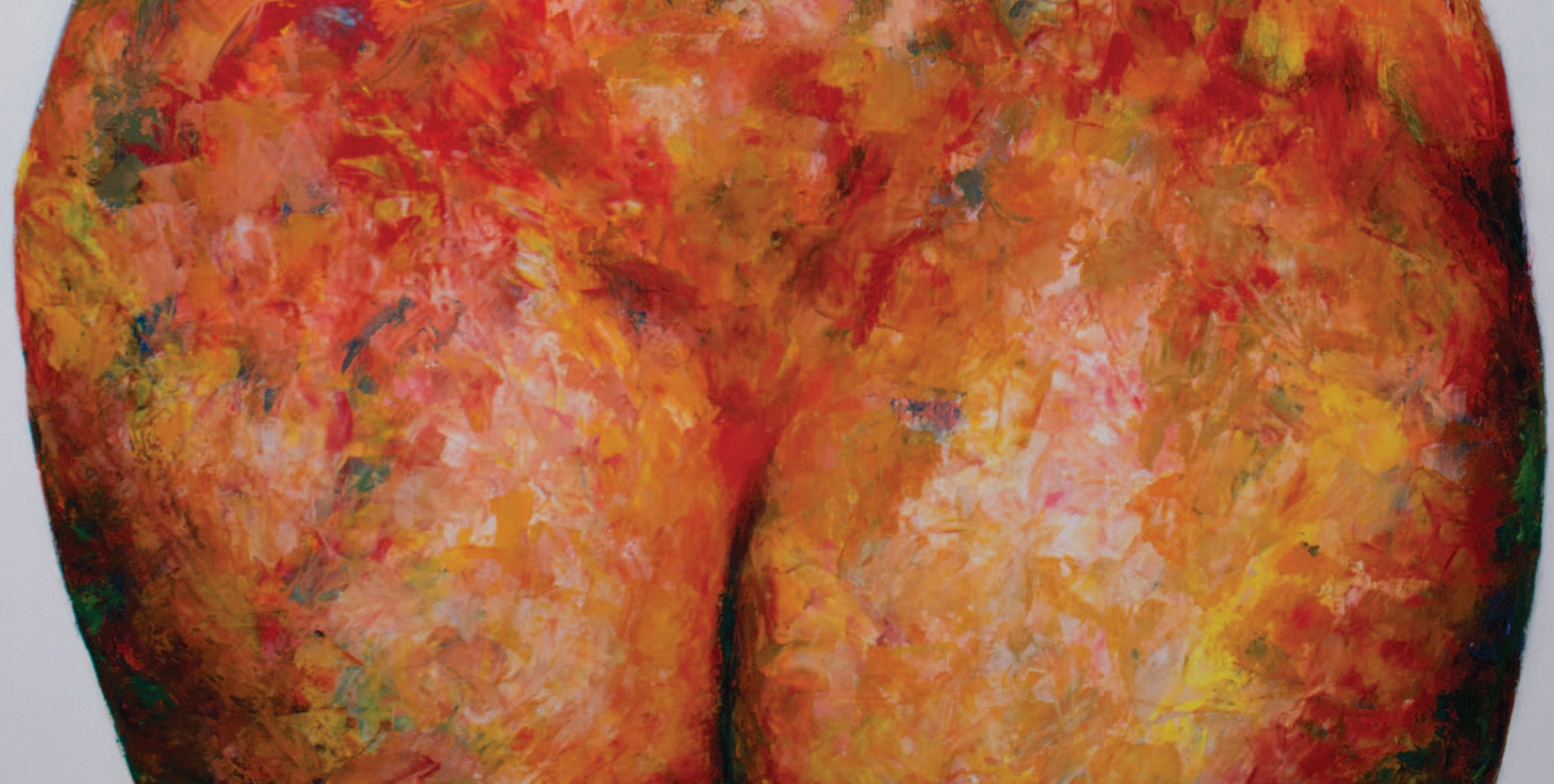




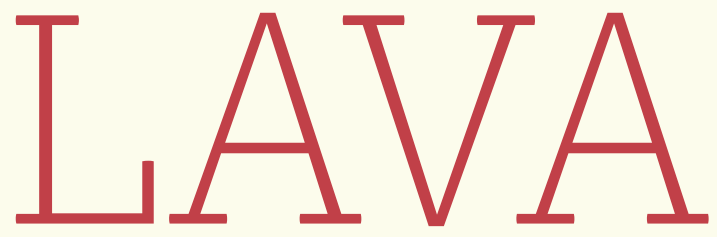

Matéria liquida lançada pelos vulcões.

Torrente, enxurrada, curso. 


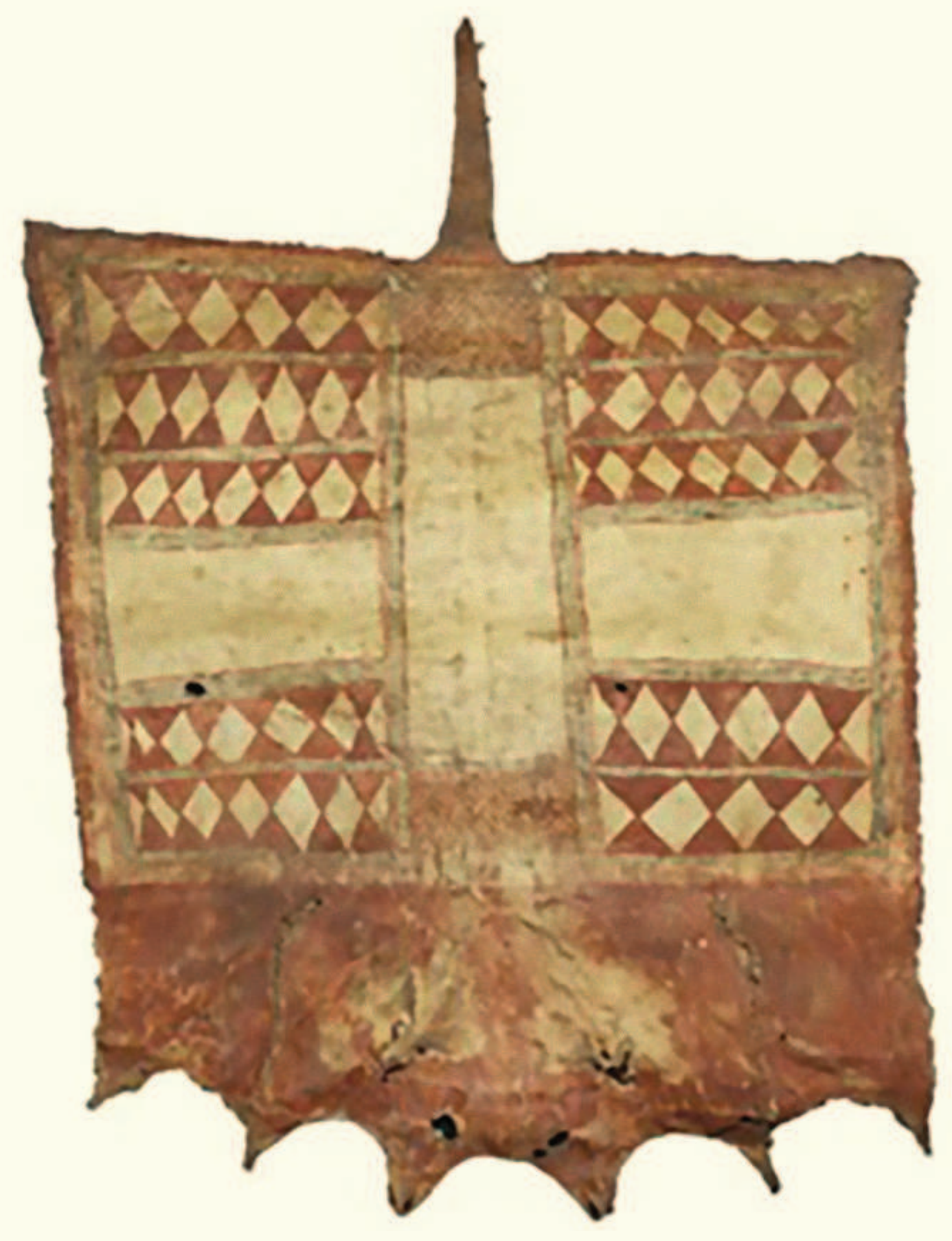

\section{LITERATURAS DA FLORESTA}

Textos de conclusão do curso ministrado no segundo semestre de 2014 e indicados para publicação pela Profa Lúcia Sá. 


\title{
JORGE DE LIMA E OS NATIVOS DA ILHA: PODEIS FRECHAR-NOS ÍNDIOS ATUAIS.
}

\author{
- DANIEL GLAYDSON RIBEIRO
}

\section{RESUMO}

Este ensaio percorre a relação do poeta, ensaísta e romancista Jorge de Lima (1893-1953) com a questão —a tragédia, o genocídio— indígena. O texto parte da Invenção de Orfeu (1952), mas retorna às origens da problemática relação através de obras menos conhecidas do autor, como Rassenbildung und rassenpolitik in Brasilien (1934), Salomão e as mulheres (1927), "Todos cantam sua terra..." (1929) e Anchieta (1934), desenhando um painel de ideologias controversas e feracidades contraideológicas. A "carnifágia" do grande poema, este experimento épico-lírico-dramático, só pode ser compreendida a partir de um duplo gesto, devorador de si próprio e violador de sua ascendência.

Palavras-chave: Invenção de Orfeu; eugenia; "mesticismo"; Indíada; "carnifágia”.

\section{ABSTRACT}

This essay focuses on the relation that the poet, essayist and novelist Jorge de Lima (1893-1953) established with the Brazilian indigenous tragedy and genocide. The argument focuses on Invenção de Orfeu (1952), but it will also trace the origins of this polemical issue in lesser-known works of the author such as Rassenbildung und rassenpolitik in Bresilien (1934), Salomão e as mulheres (1927), "Todos cantam sua terra...” (1929) and Anchieta (1934). This sequence will allow me to present a broad panel in which ideological and counter-ideological elements appear in a controversial and productive manner. The "carnifágia" that is at play in this great poem, this epic-lyric-dramatic experiment, can only be understood by the unfolding of a double gesture: auto-cannibalization and the rape of its own ascendancy.

Keywords: Invention of Orpheus; eugenics; "mesticism"; Indiad; "carnifágia".

A Maria Augusta Fonseca, Fábio de Souza Andrade, Gustavo Angelelli, Lúcia Sá e aos Orari-mogo-dogue. 
T nagouvo, ivadaruvo oinno, ivo boeddo oinno rabodde, ia aivore ivo, ia

Iéture ivu, ia bia pagare ivu, ure ia iedaga mague, imana mague, ia ituie mague, ia imuga mague ero ginno, ego ginno, evadaru ginno, ure eddo boe ginno, ure eddo tugue boiddo bugororoddo puddui, ure exebaddo boeruxe, bubutuxe, ure exebaddo quigori, baxe, tomugue, ure exebaeddoixebae jameduxe; ekodda, etavara rema carega, eeda rema carega, ro pega care ei, aco pega care ei, bataru pega care ei; ikodda rema carega, itavara rema carega, ia rema carega, pemega care, birigoddu care, ro pemega care, aco pemega care, bataru pemega care, ró, aco, bataru irigoddu care.

Tiago Marques Akirio Bororo Keggeu Discurso noturno, 19.XII.1939 ${ }^{1}$

"A ilha ninguém achou / porque todos a sabíamos. / Mesmo nos olhos havia / uma clara geografia." (LimA, 1952, 18). Entre as possibilidades de compreensão dessa memória ancestral e óptica a que alude a primeira quadra do segundo subpoema da "Fundação da Ilha", no Canto Primeiro da Invenção de Orfeu (1952), gostaria de começar por uma exacerbadamente imagética e porventura fantasiosa, que nos envia há mais de 200 milhões de anos, quando a Terra era constituída, em sua parte seca, pelo supercontinente conhecido como Pangeia. Não parecia o planeta, àquela altura, um grande e estranho olho, íris a terra e esclera o oceano (como arriscadas tatuagens contemporâneas), a rodar e transladar pelo universo (e talvez, já então, vigiá-lo)? Grande olho para nós, pequeníssimo para o Cosmos. Uma mirada à representação do corpo celeste na era Paleozoica me sugere essa imagem, bela ou grotesca: dar as costas marítimas ao Sol para que houvesse noite era o fechar pálpebras da Terra. Essa leitura suprarreal dos versos entende que, se as ilhas-continentes já foram uma só, "todos a[s] sabíamos": memória pétrea, das "rochas vigilantes" (1952, p. 48). Paisagens alógicas.

[1] Tradução e parênteses dos missionários salesianos: "Era para que eu falasse, para que dissesse, para que fizesse assim; foi um ser (Deus) que me olhava, que me escutava, que me dirigia. Ele fez que meus avós, meus irmãos, minhas mães (os missionarios) assim fizessem, assim dissessem, assim falassem; ele (Deus) fez que padecessem a fome, fez que sofressem o calor, a chuva, fez que sofressem as morissocas, os pernilongos, os borrachudos, fez que sofressem tudo o que eu sofro. / Lá nas suas veredas não é assim, seus caminhos não são assim, nos seus lugares não é assim, não faz mal a eles, não diz mal deles, não fala mal deles; a minha vereda, o meu caminho, o meu lugar não é bom, não é gentil, não faz bem, não fala bem, porque o seu fazer, seu dizer, seu falar não agrada tão facilmente." (BoRoRo KegGeu apud Colbacchini; Albisetti, 1942, p. 25, 27). 
Evoluindo dessa interpretação pré-histórica, devemos ir-nos achegando, milhões de anos depois, à história ou ao mito. A "clara geografia" -não achada, muito menos descoberta - de que nos fala o narrador ou o rapsodo da Invenção de Orfeu, faz pensar nas diversas viagens à "Ilha" em muito anteriores à institucionalizada ibérica, especialmente a do irlandês São Brandão, o Navegador, que no século VI saíra à procura do Paraíso em alto mar, a Terra Repromissionis Sanctorum, e encontrara estas (ou outras) Ilhas Afortunadas, ${ }^{2}$ como registra o ramo de textos latinos Navigatio [ou Peregrinatio] Sancti Brendani Abbatis, uma espécie de "«odisseia monástica», um bestseller da Idade Média" (LANCIANI, 2003, 51), do qual remanesce grande número de manuscritos dos sécs. IX a XII. "Capitão-mor, capitão-mor / quereis me dizer onde é que fica / a ilha de São Brandão?" (1950, p. 272), pergunta o sujeito lírico de Tempo e Eternidade (1935), em "A Noite Desabou Sôbre o Cais": a primeira aparição do termo "ilha" na obra limiana.

Para melhor nos situarmos entre esta noite desabada e a "clara geografia", leiamos um dos relatos do achamento ou do vislumbre celta, segundo o manuscrito d'Alençon do séc. X (em que se avista um Guia, como será Virgílio para Dante, e estes e incontáveis outros para Lima):

[...] Transactis vero diebus XL vespere imminente cepit eos caligo grandis ita ut vix alter alterum potuisset videre. Procurator autem ait Sancto Brendano:«Scitis quae est ista caligo?» Sanctus Brendanus ait: «Quae est?» Tunc ait ille «Ista caligo circuit illam insulam quam queritis per septem annos». Post spacium unius horae iterum circumfulsit eos lux ingens et navis stetit ad litus. Porro ascendentibus de navi viderunt terram speciosam ac plenam arboribus pomiferis sicut in tempore autumnali. Cum autem circuissent illam terram nulla affuit illis nox.

Accipiebant tantum de pomis et de fontibus bibebant. Et ita per XL dies perlustrabant terram et non poterant invenire (finem illius). Quadam vero die invenerunt flumen magnum vergentem per medium insulae.

[2] Escreve Affonso Arinos: "[...] como é sabido, o nome de Terra do Brasil já era famoso muito antes da descoberta da America. Designava uma daquellas ilhas phantasticas, no genero das Hesperides ou de S. Brandão, e fluctuou, durante seculos, nas lendas e nas cartas geographicas, emergindo dos mares mysteriosos, ao sabor da imaginação dos cartographos." (1937, p. 23-24). Aproveito a cita para registrar que manterei aqui a ortografia "ao sabor da imaginação" das respectivas épocas, autores e revisores. 
Tunc Sanctus Brendanus conversus fratribus suis ait: «Istud flumen non possumus transire et ignoramus magnitudinem illius terrae». (AnÔNIMO, ca. 900) ${ }^{3}$

A geografia, mais do que clara, é ofuscante, mas somente porque contrapontua espessas, infensas trevas, como na dialética extrema da Invenção de Orfeu: "descobrimos nas ondas essas algas, / essas Índias tão nuas, êsses ventos, / essas admirações em São Brandão! / [...] / $\mathrm{Ah}$ ! as praias e as tragédias e as Ineses, / e os presságios bilingües, multilingües / e as visões tão fatais, tão desabridas!" (1952, p. 49). Curiosamente, o crítico português Hélio Alves, ainda que responsável por uma arguta leitura da Invenção de Orfeu, ao comentar esta passagem do subpoema XXVIII do Canto I, fala de "histórias trágicas das praias de África" (1993, p. 120), como se as praias brasileiras tivessem realmente ficado imunes.

\section{A ILHA NINGUÉM ACHOU}

Como seriam os seus impetos, os seus transes, as suas rendições, sob a trama insidiosa da raça, dos annos, da esthesia?

JORGE DE LIMA Salomão e as mulheres (1927)

Entre a pré-história e a Idade Média, houve uma célebre batalha entre ilhas: de um lado, Atenas; do outro, Atlantes, como imortalizara o discurso inacabado do Crítias de Platão. Muito se discutiu sobre a realidade ou a invenção de tal ilha bárbara, e ainda em Rassenbildung und rassenpolitik in Brasilien ("Formação e política raciais no Brasil", publicado em Leipzig em 1934, mas escrito dez anos antes, segundo afirma o prefaciador Hans Bauer), Jorge de Lima declara sua suspeita

[3] "Depois de uma viagem de quarenta dias, ao cair da noite, profundas trevas os envolveram, a ponto que não podiam quase ver-se um ao outro. O guia disse então a São Brandão: «Sabes o que são estas trevas?». São Brandão perguntou: «O que são?». O guia respondeu-Ihe: «Estas trevas circundam a ilha que tu procuras há sete anos». Pouco depois uma luz intensa inundou-os de novo e a nau achou-se ancorada. Desembarcados, viram uma terra imensa e coberta de árvores carregadas de frutos como no Outono. Depois de terem dado uma volta pela ilha, deram-se conta de que não caía a noite. // Recolhiam frutos e bebiam a água das fontes, à vontade. E durante quarenta dias percorreram todo o país sem conseguir encontrar o fim. Um dia descobriram um rio enorme que corria ao centro da ilha. São Brandão disse aos seus irmãos: «Não podemos atravessar este rio e ignoramos a grandeza desta ilha»." (apud LANCIANI, 2003, p. 52). 
de que a Atlântida fosse o que hoje conhecemos por Brasil, uma Ilha, ora pois, se visualizada arquetipicamente desde o rio Amazonas até a bacia de La Plata, o que o autor chama de "Archi-Brasilien". No primeiro dos dez breves capítulos dessa obra estranha, intitulado "Brasilien - das Atlantis der europäischen Mythe”, o jovem Lima menciona Platão, Aristóteles, seis historiadores da Antiguidade, sobretudo Deodoro Sículo, e ainda o botânico von Martius para defender sua hipótese, amparado nas descrições fabulosas do clima, paisagem e flora da Atlântida, cuja profusão de espécimes só poderia corresponder à encontrada em solo brasileiro. ${ }^{4}$

Se corroboro a informação do prefaciador a respeito da composição do Rassenbildung und rassenpolitik, situando-a em meados da década de 1920 —o que é bastante plausível, inclusive pelo fato de que já constava um anúncio desta obra, "a sahir", na contracapa do romance Salomão e as mulheres (1927), com um título algo diferente, "Die geschichtlichen und nationalen Grundlagen für die zukünftige Kulturentwickelung des brasilianischen Volkes." (digamos que "As raízes históricas e nacionais para o futuro desenvolvimento cultural do povo brasileiro")-, encontram-se então neste livreto as primeiras palavras de Jorge de Lima sobre os nativos da Ilha ${ }^{5}$, um lugar nada hospitaleiro para abrigá-las, por se tratar de obra científica em que o "Doktor der Medizin" se mostra partidário do darwinismo social e das ideias eugenistas de Oliveira Vianna, Georges Vacher de Lapouge, etc., defendendo por conseguinte o "embranquecimento" gradual da população brasileira como processo de ordem natural: "Wir wollen damit sagen, daß auch unter den Mestizen als solchen in der Entwicklung der Generationen sich der Einschlag des weißen Bluts immer mehr durchsetzt und sie mehr und mehr reinrassig macht." (1934, p. 40). ["Com isto queremos dizer que também entre os mestiços, tal como no desenvolvimento das gerações,

[4] De fato, por estes "mais de dois milénios de exegese" em busca de definir a localização exata da ilha dos atlantes, uma das possibilidades é (ou foi) a América, desde sua Conquista ou Invasão, segundo anota o tradutor e filósofo lusitano Rodolfo Lopes: "Sobretudo a partir dos Descobrimentos portugueses e espanhóis dos séculos XV e XVI, surgiram variadíssimas tentativas de identificar geograficamente o território. No entanto, o único resultado que todas essas demandas (mais ou menos científicas) obtiveram foi uma disparidade de opiniões tal que tornou qualquer ponto do globo passível de ser identificado com a ilha. [...] a grande maioria dos títulos que têm sido publicados sobre a Atlântida, ou que, de algum modo a abordam, tomam como princípio a sua anistoricidade." (LopEs, 2011, p. 58, 55)

[5] Obviamente que sempre podem aparecer palavras anteriores, mais ou menos específicas, como as do soneto "Meu Decassílabo", publicado em 1913 e recolhido na Juvenília: "Por mais indefectível que pareças, / Homem, serás d’uma outra vida a imagem, / pois justo é que tu nasças e pereças, // -herdeiro dos pavores do Selvagem / e dos vícios, das dôres, das desgraças / originárias de milhões de raças..." $(1950,26)$. 
o impacto do sangue branco prevalece sempre mais e torna-os cada vez mais de raça pura."] Traduzo Einschlag por impacto, mas: e se o traduzisse por trama? Entre as influências deste Jorge de Lima, não se pode deixar de mencionar Euclides da Cunha e, através deste, Ludwig Gumplowicz: "A civilização avançará nos sertões, impelida por essa implacável 'força motriz da História' que Gumplowicz, maior do que Hobbes, lobrigou, num lance genial, no esmagamento inevitável das raças fracas pelas raças fortes." Estas palavras da "Nota Preliminar" de Os Sertões são citadas por Jorge de Lima em 1943 como sendo "desoladoras", em um artigo que ataca o "assunto fecundo da eugenia de hoje", sem mencionar explicitamente o seu próprio Rassenbildung da década anterior: "solicitamos maltusianismo contra tanta literatura quase frascária” (LiMA, 2002, p. 179, 181).

Esta publicação é um enigma no conjunto da obra de Jorge de Lima: "Fazendo-se antropólogo, ainda em 1935, publicou o ensaio de comprido título em alemão, do qual muito se fala, mas pouca gente leu" (BANDEIRA, 1959, p. 66). Um dos únicos estudiosos que realmente se manifesta acerca de tal obra é Roger Bastide, entre 1943 e 47 (devido à incerteza quanto ao ano de publicação do estudo Poetas do Brasil), com o raro olhar do franco-afro-brasileiro:

[...] o trágico de Jorge de Lima tem algo do remorso do assassino. Após haver sustentado que o elemento africano estava fadado a desaparecer, que o Brasil caminhava para uma arianização e um "embranquecimento" progressivo do sangue, após haver sustentado uma política racial que intensificava a obra de seleção pelo desaparecimento dos mais escuros, o poeta se revolta contra o médico que redige um atestado de óbito e escreve: "Os netos de teus mulatos e de teus cafusos / e a quarta e a quinta gerações de teu sangue sofredor / tentarão apagar a tua cor! / E as gerações dessas gerações quando apagarem / a tatuagem execranda, / não apagarão de suas almas, a tua alma, negro!". Sua poesia vai procurar numa ausência de africano o que subsiste ainda de africano, em piedosa e ao mesmo tempo desesperada peregrinação (1997, p. 48).

(Pode-se dizer o mesmo sobre a relação do poeta com a ausência do indígena? Pergunta final deste ensaio.)

Em Rassenbildung, o foco se volta para o índio no quarto capítulo, "Brasiliens Ureinwohner", cuja primeira fonte é o controverso naturalista Hermann von Ihering e seu texto "A Civilização Pré-Histórica do Brasil Meridional" (1895), em que, a partir de escavações (ou saques) 
de sambaquis, tidos como "restos da cultura prehistorica", se defende a tese de que os povos andinos, como habitantes do único "centro de civilisação superior" da América do Sul, teriam influenciado povos mais primitivos como os Guaranis e os Marajoaras, numa espécie de estrutura em "circulos ondulatorios" (1895, p. 155): quanto mais perto dos Andes, mais civilizada - ou menos incivilizada - seria a tribo ${ }^{6}$. Jorge de Lima, após mencionar os três estágios de cultura ou "typos caracteristicos de antiguidades sul-americanas" propostos por Ihering, isto é: "um povo de pescadores que moravam ao longo da costa", "habitantes das mattas" e "Indios dos campos" (1895, p. 102-104, cito o original do cientista alemão), e em seguida elencar diferentes níveis de organização social entre os "bárbaros" ("barbarisch"), Lima avança para a questão da religiosidade nativa e as diferentes opiniões dos "nossos etnólogos", divididos entre o politeísmo, como afirmado pelo General Couto de Magalhães em O Selvagem (1876), ou a simples impossibilidade de se conceituar como politeístas ou monoteístas, dado que ambas requerem um desenvolvimento mental e/ou espiritual ("geistige Entwicklung") que não havia sido alcançado, segundo defendem Silvio Romero e José Veríssimo —ideia que não parece ter avançado muito em relação aos cronistas do séc. XVI, quando se afirmava a plenos pulmões a total inexistência de religião entre os índios, como faz André Thevet, ou pelo menos a sua ignorância de Deus, nos termos de Jean de Léry, ainda que este último faça questão de ressaltar o conhecimento dos selvagens acerca da imortalidade das almas e da ressurreição dos corpos-.

Considerando então a existência de uma "fase de crença inconsciente em espíritos" ("Phase des unbewußten Geisterglaubens"), Jorge de Lima recorre ao conceito de homem primitivo em David Hume, segundo o qual, na busca de explicações, aquele tende a projetar na causa desconhecida a sua vaga razão, tanto quanto a sua aflorada paixão, e ainda seus membros e sua face. Jorge não indica de onde adaptou e traduziu o conceito de Hume, mas ele advém da obra The natural history of religion

[6] Como primeiro diretor do Museu Paulista, de 1894 a 1915 (substituído por Afonso d'Escragnolle Taunay), Hermann von Ihering é um dos responsáveis pela "política colonial" que levantou a bandeira do progresso rumo ao oeste do Estado, com ou sem os Kainguangues que por ali habitassem. Em textos como "A Antropologia do Estado de São Paulo" (1907), chega a propor o extermínio desses índios "primitivos e perigosos" (IheRING apud FERREIRA, 2009, p. 69). Sigo de perto o artigo de Lúcio Menezes Ferreira, "Diálogos da arqueologia sul-americana...", inclusive no uso do termo "saque" para referir-me às escavações em sambaquis. 
$(1751)^{7}$. Vale perguntar se o "homem primitivo" que assim atua, para o grande empirista e cético escocês do séc. XVIII, não seria simplesmente o homem, sem adjetivos de barbárie ou civilização, como se lê em outro de seus livros: "We have no idea of the Supreme Being but what we learn from reflection on our own faculties." (1910, p. 51). Mas isto já são outras contradições ou, melhor dizendo, outras estratégias retóricas.

Pois bem, ao final do capítulo sobre os nativos brasileiros, em um lampejo que parece ultrapassar as suas leituras etnográficas da época e poderia, se considerado a fundo, colocar em xeque o fundamento ideológico de toda a obra, isto é, a famigerada hierarquia racial (étnica ou cultural, para nos valermos dos termos mais ou menos atuais), Jorge de Lima aproxima, en passant, a religiosidade do indígena com aquela da raça prototípica para certo Ocidente ${ }^{8}$, ao equiparar o Tupã dos Guaranis ao Zeus dos Gregos, naturezas antropomórficas de aquém e de além-mar, deuses que se manifestam, ocasionalmente, por meio de terríveis furacões": "Tupan war für die Guaranys, was Zeus für die Griechen war, der sich auch ihnen zuweilen durch fürchterliche Orkane offenbarte" (1934, p. 23).

[7] Em que se lê, por exemplo: "We may as resonably imagine that men inhabited palaces before huts and cottages, or studied geometry before agriculture; as assert that the Deity appeared to them a pure spirit, omniscient, omnipotent, and omnipresent, before he was apprehended to be a powerful, though limited being, with human passions and appetites, limbs and organs. The mind rises gradually, from inferior to superior: by abstracting from what is imperfect, it forms an idea of perfection: and slowly distinguishig the nobler parts of its own frame from the grosser, it learns to transfer only the former, much elevated and refined, to its divinity." (HumE, 1889, p. 3-4). ["Seria tão razoável imaginar que os homens habitaram palácios antes de choças e cabanas, ou que estudaram geometria antes de agricultura, como afirmar que conceberam a divindade sob a forma de puro espírito, onisciente, onipotente e onipresente, antes de concebê-la como um ser poderoso, ainda que limitado, dotado de paixões e apetites humanos, de membros e órgãos. O espírito se eleva gradualmente do inferior para o superior: por abstração, forma, a partir do imperfeito, uma idéia da perfeição, e lentamente, distinguindo as partes mais nobres de sua própria constituição das mais grosseiras, aprende a atribuir à sua divindade somente as primeiras, as mais elevadas e puras." (2005, p. 24-25)]

[8] Seligmann-Silva, ao citar e comentar Le mythe nazi (1991) de Lacoue-Labarthe e Jean-Luc Nancy: "'o mito, como a obra de arte que o explora, é um instrumento de identificação. Ele é mesmo o instrumento mimético por excelência’. Esse mimetismo exige certos tipos (modelos) que devem garantir a construção da identidade. No caso da Alemanha, essa construção teria se dado em oposição às nações 'já formadas' como a França e a 'Itália'. O específico da Alemanha consiste, segundo os autores, na sua identificação com uma Grécia mítica/ mística que teria sido 'descoberta' por autores alemães no final do século XVIII (em oposição à Grécia 'clássica' italiana e francesa) como o tipo a ser imitado” (2005, p. 304).

[9] Neste sentido, vale citar ainda uma passagem curiosa de Jean de Léry: "Et parce aussi, comme ie diray plus au long, que quand ils entendent le tonnerre, qu'ils nõment Toupan, ils sont grandement effrayez : si nous accommodans à leur rudesse, preniõs de là particulieremẽt occasion de leur dire, que c'estoit le Dieu dont nous leur parlions, lequel pour monstrer sa grandeur \& puissance, faisoit ainsi trembler ciel \& terre : leur resolutiõ \& response à cela estoyent, que puis qu'il les espouuantoit de telle façon, qu'il ne valoit donc rien. Voila, choses deplorables, où en sont ces pauvres gens." (1580, 233). Na tradução brasileira de Sérgio Milliet, realizada a partir da edição de Paul Gaffarel, não consta a importante relação inicial entre o trovão e Tupã: "E quando ribombava o trovão e nos valíamos da oportunidade para afirmar-Ihes que era Deus quem assim fazia tremer o céu e a terra a fim de mostrar sua grandeza e seu poder, logo respondiam que se precisava intimidar-nos não valia nada. Eis o deplorável estado em que vive essa mísera gente.” (1941, p. 188). 
É deveras interessante essa proximidade entre o arquétipo da civilização ocidental e os "bárbaros" do Novo Mundo. Tratando dos Araweté, por exemplo, Viveiros de Castro anota que "um curioso epíteto continua a marcar os deuses como selvagens: me'e wi a-re, 'comedores de carne crua"; e em nota de rodapé, recorda "que um dos epítetos de Dionísio era exatamente este: ōmēstếs ou ōmádios, "comedor de carne crua"” (2013, 270). Michel de Montaigne, por sua vez, em seu célebre ensaio sobre os canibais, após citar uma canção de amor dos índios e julgá-la "tout a fait Anacreontique", arremata: "Leur langage, au demeurant, c'est le plus dous langage du monde, et qui a le son le plus agreable a l'oreille : il retire fort aux terminaisons grecques" (1870, p. 180). E os jesuítas, por fim, chamavam a língua tupi de "grego da terra". Ao aproximar mitos, logo caímos nesta in-certa afluência das línguas, este nexo originário - Ur-nexo- ou estxs irmãxs gêmexs - "the primitive mind myth and language are, as it were, twin brothers" (CASSIRER, 1944, p. 143)-.

Como Roger Bastide demarca, há uma diferença crucial entre o posicionamento ideológico do Dr. Jorge de Lima, e aqueloutro do poeta. E acrescento: do romancista. No exato Salomão e as mulheres que anuncia o ensaio em língua alemã na sua contracapa, já se imprimia uma visão mais dinâmica e mestiça das raízes nacionais. O que não significa, todavia, e o mesmo pode ser dito sobre a poesia negra, que o autor em algum momento consiga se "purificar" das ambiguidades e, logo, da polêmica:

$-[. .$.$] Em contato com o advena mais forte e mais productor o segundo$ Brasil desapparecerá como o primeiro.

- A que Brasil desapparecido se refere o Reverendo?

- Ao legitimo, ao Brasil tupi, ao Brasil tapuia, ao Brasil indigena que fugiu para o mato, com medo.

— Mas o actual resiste, reage.

- O actual é o ibero-celto-celtibero-phenicio-troiano-hebraico-grecocarthagino-romano-suevo-alemano-visigodo-arabico. — o luso, emfim, combinado ao afro-tupi ...

Esse amalgama inda não estavel nem sedimentado — arvore humana, joven - vem soffrendo e vae soffer com maior intensidade a pressão da selva barbara: espanhóes, italianos, germanos, slavos, syrios, mais tarde japonêses ... De todos os lados o imbé nacional sofferá o arrocho, 
premido pelas raizes. Suffocando nos ramos, esgueira-se á procura do céu, do cruzeiro do sul ...

- Mas é facto biologico, retorqui: o ramo que se esgueira, que se estira, na lucta pela vida, pelo ar, nas florestas americanas, dá em cipó, cipó sinuoso mas forte e victorioso que floresce em paniculas perfumadas, que esmaga, que comprime, que estrangula, que mata para vencer. (1927, p. 19-20)

O narrador do romance está tão amalgamado a suas personagens que mal podemos afirmar se o parágrafo que inicia sem travessão, nesta cita, é um prolongamento da fala do "Reverendo", o Padre-Mestre Josué, ou uma interferência do narrador, a que o protagonista Fernando retorque, aproveitando o embalo da metáfora botânica. Cipó de imbé, aliás, é o primeiro título deste romance, em sua versão primitiva de 1922 (logo, palavras anteriores ao Rassenbildung?).

\section{PORQUE TODOS A SABÍAMOS}

All of old. Nothing else ever. Ever tried. Ever failed. No matter. Try again. Fail again. Fail better.

SAmuel BeCKetT, Worstward Ho (1983)

No mesmo ano em que o Rassenbildung und rassenpolitik sai em Leipzig, a Biblioteca Brasileira de Cultura dirigida por Tristão de Athayde lança Anchieta (1934), pouco após sua publicação durante oito domingos, entre setembro e outubro de 1933, no suplemento literário do Correio da manhã. O projeto inicial do polígrafo alagoano era compor uma "Psicologia Religiosa do Brasileiro", do qual desiste a tempo, salvando dele apenas a hagiografia de José de Anchieta —o texto trata-o por santo, independente de a canonização ter advindo somente com o Papa Francisco, porque crê, ainda que sempre num aparente tom de galhofa, nos milagres do "pagé de roupeta" (1934a, p. 74)—. Segundo explicação que o autor apensa à quarta edição, não o teria transformado em livro se não fosse o ânimo de Paulo Prado: "Mal chega domingo fico ansioso pela sua história. Você inventou um processo novo de contar a vida do apóstolo. Intimo-o a publicá-lo em livro quanto antes" (apud LimA, 1958, p. 1039). O que Jorge de Lima não inventa ali é um "processo novo" para contar a vida da "indiaria", "Aquella gente [que] não era o grego, não era o coryntho, não era o galata, não era o chinês, não era o puritano. Não se podia prender aquella gente nem a 
epistola nem a pistola. Nem com São Paulo nem com Argall", e segue reafirmando o tópos da infantilidade nativa ${ }^{10}$ — "Aquela gente era criança. E nas crianças ninguem pode corrigir as criançadas da noite para o dia"-, mas com a visão orlada de cristianismo: "Não pensem que eu estou desgostoso com isto. Não estou não, Jesus até gostava era das crianças. Os escribas, os doutores do templo, Elle verificou que sabiam pouco. As crianças é que sabiam tudo" (1934a, p. 48-49).

Neste trecho, Jorge de Lima está reescrevendo "Todos cantam sua terra..." (Dois ensaios, 1929), ali onde o próprio fazer literário dos modernistas, e afinal o Brasil, aparecem, sem qualquer desgosto, como brincadeira de criança. "A gente faz isso e outros brinquedos de tinta, quando a gente tem força de descer á criança. [...] A tinta vermelha do tinteiro do subconsciente do Mario deu um borrão parecido com o Brasil : Macunaima". "Todos cantam sua terra..." é ao mesmo tempo o ensaio mais equivocado, mais contundente, mais controverso que Jorge de Lima publica, acumulando preconceitos de época ${ }^{11}$ mas também antidogmatismos, aproximando sincretismo religioso e "pornographia", tudo impulsionado pela ideia de um "raide do subconsciente nacional" que, a seu ver, caracteriza a rapsódia recém-publicada de Mário de Andrade, motivo primeiro de toda a dispersão textual. "O heroe deixa de ser portanto o Macunaima para ser o proprio Mario. Outros em todos os tempos têm tentado a viagem, dêsde Basilio e Durão até hoje. / Mas esse pessoal não tinha os motores e as asas de Mario" (1929, p. 126, 120, 127). Das viagens épico-nacionais, apenas o "mano" Mario e o Euclides da Cunha teriam sobrevivido, segundo este Jorge de Lima, que atualiza e alarga absurdamente um juízo crítico mais ou menos comum a respeito das nossas epopeias —em tonalidades diversas, algo próximo pode ser lido não apenas no mencionado "grande crítico que foi

[10] Segundo Affonso Arinos, "não era difficil aos estrangeiros convencer os indios de que deviam acompanha-los. Ao contrario, estes ultimos é que se offereciam com açodamento, almas infantis que eram, imprevidentes, desconhecendo os riscos e amando as aventuras. Provavelmente, se sentiriam engrandecidos no conceito dos patricios, com a ideia de que partiam dentro daquellas embarcações bizarras, em companhia de seres tão estranhos, em busca de costumes superiores." (1937, p. 62). Ou segundo um verso de Reynaldo Jardim gravado por Maria Bethânia: "O que se odeia no índio é a permanência da infância."

[11] No momento mais infeliz do texto, o ensaísta defende que o "O perigo da indefinição deveria amedrontar-nos tanto quanto amedronta o alemão de hoje quase afogado pelo judeu” (1929, p. 133). Como nos lembra Alexandre Eulalio, tratando do ensaio sobre Marcel Proust que completa esse volume, "perpassam ainda algumas idéias feitas bem de época sobre a condição judaica, de que o autor só parece ter se desfeito no decênio seguinte, quando se torna o tradutor do volume coletivo de Maritain Os Judeus, que celebra a fraternidade cristã com o 'povo eleito'” (1983, p. 6). A título de registro, vale anotar que a atribuição do volume a Jacques Maritain é erro da edição brasileira, pois este foi organizado por Paul Claudel. Diria ainda que o volume também não está isento da polêmica, pois na busca de compreender o milenar dilema histórico-religioso, prestes a explodir em novo holocausto, dispõe de textos filossemitas e antissemitas. 


\title{
José Veríssimo", mas também em Silvio Romero ${ }^{12}$ ou Fidelino de Figuei- redo, mas nunca com tanta violência-:
}

\begin{abstract}
Houve de facto ausencia de Brasil nos antigos, hoje parece que ha Brasil de proposito nos modernos. Porque nós não poderíamos com sinceridade achar Brasil no indio que Alencar isolou do nêgro, cedendo-lhe as qualidades lusas, batalhando por um abolicionismo literario do indio que nos dá a impressão de que o escravo daquelles tempos não era o preto, era o autochtone. O mesmo se deu com Gonçalves Dias em que o indio entrou com o vestuario de pennas pequeno e escasso de mais para disfarçar o que havia de Herculano no escriptor. [...]
\end{abstract}

Não havia realidade nesta literatura. Como não havia no nêgro de Castro Alves elevado a espartaco e servido do pior romantismo do mundo que foi o de Hugo. [...]

Entretanto nós precisamos achar a nossa expressão que é o mesmo que nos acharmos.

E parece que o primeiro passo para o achamento é procurar traser o homem brasileiro á sua realidade ethnica, politica e religiosa.

Essa expressão falhou em tantas tentativas : O Uruguay, o Caramurú, os Timbiras, a Confederação dos Tamoios, O Colombo, O Guarany e

[12] Olavo Bilac e Guimarães Passos citam o trecho a seguir de Sylvio Roméro em seu Tratado de Versificação (1905) como "uma pagina que deve ser sempre lida e relida : «O poema epico é hoje uma fórma litteraria condemnada. Na evolução das letras e das artes ha phenomenos d'estes : ha fórmas que desapparecem; ha outras novas que surgem. Além d'esta razão geral contra nossos poemas epicos, existe outra especial e igualmente peremptoria : o Brasil é uma nação de hontem ; não tem um passado mythico, ou se quer um passado heróico ; é uma nação de formação recente e burgueza; não tem elementos para a epopéa. É por isso que todos os nossos poemas são simplesmente massantes, prosaicos, impossiveis. A Independencia do Brasil, a Confederação dos Tamoyos, o Colombo, os Tymbiras, os Filhos de Tupan, a Assumpção da Virgem, o Villa-Rica e outros, são productos mortos, inuteis. Nossos poetas são por essencia lyristas ; não têm, não podem ter vôos para a epopéa. D’esse naufragio geral salvam-se apenas o Uruguay e o Caramurú. O que os protege é o seu tempo ; appareceram a propósito ; nem muito cedo nem muito tarde. Não era mais nos primeiros tempos da conquista, quando ainda não tínhamos uma historia ; não era também nos tempos recentes, em meio de nossa vida mercantil e prosaica. Era no século XVIII, quando a colonia sentia já a sua força, sem as suas desillusões.»” (1905, p. 95-96). Como se lê em "Todos cantam sua terra...”, Jorge de Lima não considera que Basílio da Gama e Santa Rita Durão tenham sobrevivido a "esse naufragio geral”. Em um artigo bem posterior, publicado em 1946 na Revista Esfera, o autor mantém a crítica e a verve: "Pretendia este ilustre grupo, com o arcadismo, desbancar o seiscentismo, mas continuou gongórico. [...] Nada mais chocante do que colocar lado a lado os versos tão brasileiros, tão amor mineiro e universal do vate portenho [Tomás Antonio Gonzaga] e os dos poemas Uruguai e Caramurú. Quer dizer que, se a Pleiade conseguiu, graças a Marilia bela, uma vitória lírica, falhou completamente ao tentar o poema épico." (1946, p. 23, grifo) [Texto constante do Álbum de recortes no 20, no Acervo Jorge de Lima - AMLB-FCRB]. 
todo o Castro Alves épico, político ou social. Quando o exagero cedeu um momento e a nossa realidade foi entrevista por um homem de genio, Euclydes da Cunha, nós tivemos Os Sertões que vencendo mesmo o empolado da linguagem escancaram uma expressão brasileira, um pedaço da gente brasileira, um bocado bom do nosso mesticismo, do nosso mysticismo e da nossa politica. (1929, p. 92, 103, grifo)

De início, a respeito de José de Alencar e o(s) "escravo(s) daquelles tempos", é preciso não esquecer que o autóctone também era forçado, inclusive no séc. XIX (e ainda hoje), a trabalhar em regime de escravidão. Basta reparar no recenseamento que Maurice Rugendas ajunta à $\mathrm{Ma}$ lerisch reise in Bresilien (Viagem pictórica ao Brasil, ou pitoresca, como prefere a tradução francesa, obra de 1835 que aliás integra a bibliografia do Rassenbildung): a província de Minas Geraes contava com 600,000 almas, entre elas 250,000 escravos negros e 40,000 escravos de cor, isto é, mulatos, caboclos, mamelucos, índios (1851, p. 27), e esta condição será relatada na própria "tentativa" épica de Jorge de Lima (a bem da verdade, épico-lírico-dramática), quando o sujeito poético assume, entre centenas de vozes, "Múltiplo imitando / mitos, sêres e coisas", também a voz do índio:

Sobretudo eu escravo do homem branco,

ó cunhãs, inocências e pobrezas,

curiosidades sôbre meus amores,

visões de missionários, flor de peles,

narrativas de naus e manuscritos,

madeiras de Colombos e de Espanhas.

Vivo estranho em Lisboas babeladas, entre chins e japões pelas ruelas, os domínios distantes me afogando, cotovelado pelo Rei das quinas, resgatado com fardos e tonéis, descoberto de trajes e de galas. (1952, p. 57)

Trata-se de uma voz deformada, aculturada, violentada. Este exílio ou encarceramento em Lisboa, que se narra, é desenhado pela forma do poema: o índio se expressa em sextilhas decassílabas. Não o metro, mas a mesma forma estrófica que Gonçalves Dias elege para as Sextilhas de Frei Antão, a fim de "extreitar ainda mais, se for possivel, as duas litteraturas - Brasileira e Portuguesa, - que hão de ser duas, mas semilhantes e parecidas, como irmãs que descendem de um mesmo tronco e que trajão os mesmos 
vestidos" (1848, p. vi). Em Invenção de Orfeu, a relação com esta "irmã" é de desnudamento e incesto. Nas duas estrofes acima transcritas da Indíada limiana, isto é, o subpoema XXXII do Canto Primeiro, o que se lê é também uma montagem obscura ${ }^{13}$ a partir de certos parágrafos um tanto mais claros de O Indio Brasileiro e a Revolução Francesa (1937), de Affonso Arinos de Mello Franco, sobre o seviciamento dos indígenas e das "cunhãs", ou sobre a capital cosmopolita e babélica da escravatura universal que havia se tornado a Lisboa do séc. XVI: "Gentes bizarras e suspeitas, negros, indios da Asia e da America, chins e japões, ao lado de heróes, soldados, navegantes, apostolos e sabios, formigavam naquellas ruelas escuras e escusas, que se enovelavam nos arredores do Palacio Real", etc. (1937, p. 56). ${ }^{14}$

Na relação com o ensaio "Todos cantam sua terra...", como explicar que Jorge de Lima, na composição de seu último poema, coloque visceralmente em prática uma estética que havia sido espezinhada por ele mesmo nos anos modernistas e inclusive em artigos contemporâneos à sua criação, como o "Poema épico" (1946)? Refiro-me ao exacerbamento

[13] Quem deu início ao desvendamento da trama inter- e intratextual que perpassa todo este subpoema foi Luiz Busatto (1987), demonstrando relações com O Indio Brasileiro e a Revolução Francesa, a Carta de Pero Vaz Caminha, Os Boróros Orientais (1942), Anchieta e Macunaíma (1928). Ainda que pesquisadores como Lúcia Sá e José Niraldo de Farias já tenham dado continuidade à tarefa (independentes da tese de Busatto, que permanece inédita), há mais por escavar no subpoema XXXII. O presente ensaio contribui em tal arqueologia, inclusive aventando o seguinte debate filológico: na edição princeps de Invenção de Orfeu, da casa Livros de Portugal, não há subpoema numerado com XXX no Canto Primeiro (do XXIX pula-se ao XXXI), o que as outras edições não seguem, modificando a designação da Indíada para XXXI. Portanto, é a ele que Mário Faustino se refere quando escreve em 1957, com sua típica verve poundiana, que "o poema XXXII, o mais longo deste canto, é uma péssima salada. É difícil encontrar coisa séria, publicada, de tão ruim gosto, em português ou em qualquer outra língua." (2003, p. 258). Fica patente na leitura de Faustino seu profundo interesse pela fanopeia e pela melopeia limianas, relegando a logopeia, as implicações históricas e sociopolíticas desta "salada" pós-antropofágica. O crítico e poeta piauiense não deixa de ser, todavia, um dos maiores lumes no baile carnavalesco que é a fortuna crítica de Invenção de Orfeu (de lixo a luxo, e vice-versa). Luiz Busatto, em sua tese, desdenha a asserção de Faustino, que demonstraria "toda imperícia do novel crítico, a radical ignorância daquilo sobre o que opina, a começar pela não percepção do erro de numeração de sua edição - que é a 1a." (1987, p. 84), claro, não havia outra. É preciso atentar para uma possível coerência deste "erro de numeração" na obra, neste longo poema rigidamente arquitetado para sugerir o caos. A segregação do subpoema XXX, ou seu salto, que faz com que o Canto Primeiro encerre em redondos 40 (quarenta) subpoemas, é tão incorrigível quanto o subpoema (um soneto) numerado como se fosse dois, "XIV e XV", no Canto Quarto. Assim, mantenho neste ensaio a "imperícia" de Faustino, e trato a Indíada limiana como subpoema XXXII. Há uma mística dos números na Invenção de Orfeu.

[14] Em 1942, Jorge de Lima publica uma espécie de resenha entusiástica à obra de Affonso Arinos, em que expõe uma leitura ainda rente e acrítica: "quase cinco séculos de poesia e revolução derivam da influência deste homem brasílico sem ambições e sem maldades [...] A descoberta do Novo-Mundo era como a própria descoberta da poesia. / Este século dezesseis essencialmente revolucionário foi ao mesmo tempo essencialmente poético. Em toda a Europa ulcerada de revoltas e de reformas nada se passa no plano da poesia que não surja natural do Brasil e seus indígenas." (1942, p. 4, 8). Deslumbramento natural de uma leitura que Jorge chegará a afirmar como ponto de partida da Invenção de Orfeu, ainda que suas reverberações finais na obra sejam incontestavelmente mais críticas ou mesmo irônicas: "E eu menino pequeno, todo penas, / com essas flechas sem leis e êsses colares / prefaciando viagens, aventuras, / narradores de petas européias, / eu sem ouros, com apenas maracás, / bondades naturais, recém-nascidas. // Eu índio diferente, mau selvagem, / bom selvagem nascido pra o humanismo, / à lei da natureza me despindo / com pilotos e epístolas, cabrais, / navegações e viagens e ramúsios, / santas-cruzes, vespúcios, paus-brasís." (1952, p. 56). 
dos motivos "á altura do vôo das rapinas" (que sobe, na Invenção, até às "harpias"); ao "contagio" (surreal e declarado) do "gongorismo" e seus "estragos"; à "literatura de imitação, de transposição quase"; e ainda ao "malabarismo palavroso que do Velho Mundo vehiculava um semicultismo. Nós sempre nos curvámos — dizia Jorge sem querer curvar-se- ao magnetismo das palavras, ao imperativo da resonancia vocabular" (1929, p. 93, 96, 97, 99). A diferença radical, o entrecorte da Invenção de Orfeu está exatamente na visceralidade da mise-en-scène dessa "transposição": para além da emulação retórica, necessariamente restrita a um cânone que torne possível o reconhecimento imediato da fonte ou da auctoritas, o "malabarismo palavroso" da Invenção se dá por meio de violentas transposições, tanto no nível da "resonancia vocabular" (a eufonia se metamorfoseia muitas vezes em blasfonia) quanto no da autoridade histórico-textual: aqui, dá-se o estupro palimpséstico, "fôlhas lhe sejam raspadas, / sombra lhe seja estuprada" (1952, p. 238).

Se há uma guerra fria entre as concepções ideológicas expostas nos ensaios e as contramanifestações na poesia e no romance, travada já ali no interior da década de 1920, tal batalha atinge sem dúvida a sua máxima espessura, ou melhor, sua apoteose barroca na Invenção de Orfeu, esta "poesia-caos, poesia-fiume, poesia-magma" (JACOBBI, 1982, p. 27), quer dizer, um rio magmático de contradicções dialéticas e astúcias retórico-escriturais. Deste modo, a "coerência subterrânea", que segundo Alexandre Eulalio perpassa toda a obra de Jorge de Lima, só pode ser compreendida em sua violência contra si mesma: a "experiência da centrifugação" (1983, p. 6) a força a regressar àquela estética que desdenhara, exatamente como uma "Inflorescencia centrífuga, (Botânica) Aquella que começa do vertice para a base" (FonSECA; Ribeiro, 1926, p. 324). Mas a inflorescência da Invenção é de "flores canibais" (1952, p. 41).

Se o ensaio de 1928-29 defende uma escrita prosaica, desavergonhada, que conserve "em tudo o mesmo tom da linguagem falada", em Anchieta Jorge de Lima dá livre voo a essa inclinação e o resultado sai controverso, pois é essa abertura ao dito espontâneo dentro do terreno naturalmente cerceado da escrita que acaba por licenciar o autor a se referir aos ameríndios, dezenas de vezes, pelo termo "bugres" ou "bugraria", como se fosse jocoso ou simplesmente habitual utilizar um vocábulo notadamente pejorativo (remonta ao latim medieval bulgàrus, búlgaro, membro da igreja greco-ortodoxa e, portanto, herético; sodomita) em uma obra cujo tema tangencia, digamos assim, a aculturação de tal "bugraria", vista com bons olhos (?). É fato que o termo pode ser encontrado na alta literatura indianista, como em "Meu Tio o Iauaretê" — “Pai meu, não. Ele era branco, homem índio não. A' pois, 
minha mãe era, ela muito boa. [...] Mãe minha chamava Mar'Iara Maria, bugra" (RosA, 1994, p. 840)—, mas neste caso o termo está na boca do personagem (ex-)índio, ironizando a voz do branco, o que é muito diferente da voz ensaística em Anchieta, que chega a manifestar em determinada passagem sua ascendência lusitana: "Aquelle mesmo reino que nos mandou degredados, degredou mais tarde gente daqui, quando não queria enforcar ou esquartejar os sonhadores de independencia e inconfidencias de todos os tamanhos e os politicos adversos" (1934a, p. 30, grifo). Degredado, tal como aqueles "dous degradados" que ficaram, diretamente das naus cabralinas, para dar início ao "acrecentamto danosa santa fe" (CAminha, 1943, Fol. 11, 13-v).

Em Invenção de Orfeu, o termo "bugres" aparece uma só vez, durante uma das encenações do estupro. Canto Segundo, "Subsolo e Supersolo", subpoema VI:

Iam bem juntos, iam resolutos, olhares cúmplices mas não impuros; andavam devagar, indissolutos num vago andar feroz e quase inútil.

Êle rodou-a. Tarde de uns outubros. Era por uns desvãos. Amado estupro. Pegou-a em cheio. Júbilos e frutos. Carinhos se chocaram. Testas, púbis.

Só me podes gozar feito ser bruto? Teu ser me dói em mim. Por que produzes as tatuagens? Queridas urzes. E êle: Pariste os filhos que há em ti íncubos?

Ela mostrou-os. Partiram mudos na escuridão. Surgiram bugres. Ela ofertou-lhes seu ubre. Estava pura, outra vez núbil. Filho, filha, mútua pendência em tudo, a mesma arena e cama. Olhou as mãos, as mãos da doce luta agarradas as duas a outra nuca. $(1952,91)$

Há alguma relação entre estas "tatuagens", produzidas pelo gozo bruto, e aquelas da virgem circense de $A$ túnica inconsútil, "Há um mar 
tatuado na virgem, com os sete dias da criação, com o dilúvio, com a morte." (1950, p. 374)? Ou seriam mais como a "tatuagem execranda" da pele negra, que já lemos no poema citado por Bastide? A tatuagem simboliza uma marca indevassável, a produção ou a invocação de um dogma, de uma constância forjada, mas sagrada. Algo diferente das pinturas ritualísticas com que se orna a pele indígena basicamente devido à mutabilidade destas marcas. Imediatamente à pergunta sobre as tatuagens, advêm "Queridas urzes", imagem vegetal mais propícia à "inconstância" ameríndia. Em outro momento, o narrador-pantomimo fala de "urzes canibais" e ainda de "flores canibais", estas como imagem (inclusive) da bomba atômica. Os estilhaços polissêmicos das palavras estão sotopostos, na Invenção de Orfeu, às ruínas barrocas da biografia e aos fósseis deformados, paradoxalmente fungíveis, da História.

$\mathrm{Na}$ ambivalência do subpoema VI, significariam estes "filhos que há em ti íncubos" tanto aqueles que estão no ovo, quanto os demônios (íncubos, versão masculina dos súcubos) que invadem os sonhos em busca de prazer sexual e roubam a energia vital do sonhador? Do gozo bruto, "Amado estupro", "Surgiram bugres": não o nascimento dos seres, que "Partiram mudos na / escuridão", mas a insurgência —a violenta cunhagem - deste novo nome que os afasta, os de-signa. Nesses estranhos decassílabos, fraturados de pausas e cavalgamentos insólitos, exaspera a recorrência tônica da vogal /u/ por todo o poema, dando-lhe uma sonoridade percussiva e talvez excessiva, de timbre sombrio e doloroso, escuro e profundo: juntos, resolutos, cúmplices, impuros, outubros, estupro, júbilos, frutos, púbis, bruto, mudos, bugres, ubre, pura, núbil, mútua, tudo, luta, nuca... Um recurso musical básico da poesia é recalcado a tal ponto que a assonância se torna ruidosa. Os pontos finais intermitentes conformam a respiração atônita da cena originária.

\section{MESMO NOS OLHOS SE OUVIA}

\footnotetext{
Abandonada, fruida, esvaziada na morte, Orfeu já não mais pensa, calado o canto forte em canto-chão da vida cortada ária, suspensa
} 
Em Anchieta, há um demorado comentário acerca da implantação do canto gregoriano entre os índios, estratégia de grande sucesso na concepção do "agiógrafo" Jorge de Lima, cuja perenidade ele próprio atesta no sertão de sua infância, que "guardou tudo o que o littoral teima em esquecer. [...] certas toadas fanhosas sem compasso, até inventadas pelo carinho de embalar o menino - são retalhos de cantochão, não tenha duvida". A simplicidade da música litúrgica, cuja monofonia advém dos salmos judaicos e dos modos gregos, teria se adaptado perfeitamente ao território ocupado, tal qual um estágio evolutivo bem arranjado, "o melhor derivativo" perante a "indigencia do canto do indigena brasileiro", "como se de proposito fôsse mandado de presente pelo papa Gregorio" (1934a, p. 92-94)...

A musica do indio era uma monodia guerreira, ("todos cantavam por um tom”, escrevia Gabriel Soares), coisa pauperrima, sem variantes, quasi, amolante de verdade, pois que só havia de excitante o que era supprido pelos gestos do pessoal. Foi Capistrano quem disse que isso parecia bastante com o cinema atual. [...] Musica desses brasilicos era uma enfieira rés-a-rés de notas eguaes num som pobrinho e horizontal, valendo tão somente pelo rythmo. O rythmo fazia tudo. Era o que variava aquela intenção de musica plana, sem nenhuma intellectualização, dirigindo-se ao corpo somente, excitando-o para a dança guerreira, para a onomatopéa religiosa, de mandingaria ou de luta. [...] Acudiam maracás, xuatês, cotecás; nos tornozelos dos indios, butoris de sementes enfeitavam e ajudavam o rythmo colossal. Catimbó. Catimbó. A monotonia varava a noite immensa, magnetizando o ambiente sagrado, escrava daquelles guerreiros, servindo socialmente o pessoal. Essa musica vencia, convencia pela azucrinação dos motivos que se repetiam ajudando a feitiçaria do pagé, encantando e commemorando coisas da tribu. [...] Um tucháua por mais poderoso que fosse possuia de seu a pobreza melodica das suas inubias, dos seus torés, das suas membys-chués ou das suas cangaêras feitas de canelas de defunto. $O$ missionario lhe trouxe o que não podiam imaginar - alimento musical, não pára o corpo, porém pára alguma coisa que o indio começou a sentir que existia dentro do corpo e que vibrava differentemente dos musculos e das mungangas de guerra. (1934a, p. 96-102)

O anacronismo é evidente: até no fragmento citado do Tratado descriptivo do Brazil (1587) de Gabriel Soares de Souza, podemos encontrar uma postura menos "amolante". Trata-se do Capítulo CLXII, "Que trata das saudades dos Tupinambás, e como choram e cantam" (segundo a 
"Edição castigada" de Varnhagen): "Os Tupinambás se prezam de grandes musicos, e, ao seu modo, cantam com soffrivel tom, os quaes teem boas vozes; mas todos cantam por um tom, e os musicos fazem motes de improviso, e suas voltas, que acabam no consoante do mote" (1851, p. 324). Também Jean de Léry, cujo deslumbramento com a sonoridade indígena o leva a ensaiar o registro de algumas frases em notação musical, quando citado por Jorge de Lima nesta passagem reduz-se a mero cronista encantado com o "tom tragico-comico" (1934a, p. 91) das festas e danças nativas. Nestes dois cronistas, há o intuito de estruturar um discurso sobre a música nativa a partir dos moldes ocidentais, que resulta problemático porque a sonoridade ameríndia não se convenciona a partir de seus tons e consonantes. Já a visão do autor de Anchieta é caudatária de uma hierarquia evolucionista entre a música do corpo, inferior, primitiva, coletiva, e a música com "intellectualização", superior, civilizada, subjetiva. É curioso notar que esta polarização terá grande importância no interior da dialética vanguardista, que poderá invertê-la. Vide a seguinte anotação de Mário de Andrade, às margens da leitura de Le langage musical: étude médico-psychologique (1911) de Ernest Dupré e Marcel Nathan:

É curioso observar que a música paupérrima dos povos primitivos, quase nunca e nada descritiva, improbabilissimamente expressiva, pode-se mesmo dizer que certamente inexpressiva, é realmente uma manifestação sensorial, representativa duma excitação fisiológica e destinada a provocar excitações fisiológicas, que em sua exasperação maior se tornam mesmo patológicas (quedas no santo, epidemias saltatórias, pajelanças, magias, etc.). Ora a música pura tem também esse exclusivo efeito. De forma que inicialmente psicológica, depois associativa (etos), depois divagativa (canto-chão) depois mais enriquecida de meios, voltando a associativa por meio da expressão sentimental e do descritivo (sec. XI a XII) ela volta às suas fontes e se torna de novo fisiológica na sua suprema expressão, que é o Classicismo, sec. XVII... ${ }^{15}$

Em Invenção de Orfeu, colossal fuga barroca (barroco-indígena), o trecho supracitado de Anchieta ressurge, não de todo negado, mas como

[15] O datiloscrito encontra-se junto ao exemplar de trabalho do Compêndio de história da música (1929), no Arquivo do Instituto de Estudos Brasileiros (IEB-USP), Fundo Mário de Andrade, MA-MMA 032, fólio 38. Agradeço sua indicação a Luciana Barongeno; e também a Telê Ancona Lopez, pela maravilhosa abertura ao diálogo. 
se fosse rasurado e sobrescrito: "Musiea desses brasilieos era uma enfieira rés-a-rés de notas eguaes num som pobrinho e horizontal, valendo tão somente pelo rythmo [...] Catimbó. Catimbó. A monotonia varava [n] a noite immensa" (estas rasuras são uma figuração precária da "fala palimpséstica"). Para uma leitura sincrônica, segue a Indíada:

Enfieira rés-a-rés de som pobrinho,
nós ilhéus engasgados com of-clides
esquecemos mandingas, pagelanças,
com êsse canto planando para danças
pra Tupã e morenas se entregar.
Catimbó. Catimbó, na noite imensa.

Há piranhas aos cachos, hoje aéreas, tingindo os arrebóis, de sangue humano; é bem melhor babar ternuras que violências, escutar qualquer cantiga, que aturar êsses bichos, onças pardas, onças pintadas, onças disfarçadas. (1952, p. 64)

"Catimbó", do tupi caa'timbó, floresta que entorpece, ou cat'imbó, árvore que queima, é uma prática de feitiçaria do Nordeste brasileiro, provavelmente surgida no séc. XVII, em que "existe quase a fitolatria, no culto da jurema", e cujo sincretismo intenso reúne desde o "baixo espiritismo" de influência europeia à "pagelança nortista”, temperada ainda por elementos africanos, e debruada de catolicismo. As aspas vêm de Mário de Andrade e sua Música de feitiçaria no Brasil (1963, "conferência literária" publicada postumamente), em que o polígrafo paulistano entende a relação entre o catimbó e a pajelança como "natural, dado o larguíssimo intercâmbio criado pelos paroaras da sêca nas suas idas e vindas à terra do excesso de água”, mas faz questão de demarcar as diferenças entre um e outro, pois (tangenciando aqui, novamente, a questão do número de deuses) o catimbó "se distingue bastante da religiosidade ameríndia por ser francamente politeista, quando mais provàvelmente a crença guaranítica era monoteista, como bem o demonstrou Fariña Nuñez nos seus 'Conceptos Esteticos'” (1963, p. 31-33). O uso do termo em Jorge de Lima assume, pois, distinto significado a depender do contexto: em Anchieta, ao utilizá-lo na descrição de um ritual de pajelança que remete ao séc. XVI, já que contemporâneo dos primeiros jesuítas na América, não pode passar senão como uma incongruência histórica entre outras. Já em Invenção de Orfeu, parece 
simbolizar o emaranhamento —ou o "mesticismo"- espaço-temporal que alicerça a concepção desta obra, seu exacerbado sincretismo de eras e de crenças, de gêneros e de estilos.

Na estrofe seguinte, o rapsodo fusiona vorazmente passagens de Macunaíma (1928), costurando a rapsódia das onças pardas que se metamorfoseiam em "fordes" ao poema em prosa "O Grande Desastre Aéreo de Ontem" (A túnica inconsútil, 1938), este do mesmo autor. Aqui, são as piranhas que se transformam em aviões de guerra, "tingindo os arrebóis, de sangue humano". No poema anterior: "Chove sangue sôbre as nuvens de Deus. E há poetas míopes que pensam que é o arrebol." (1950, p. 370). O sangue, que outrora chovia apenas nas nuvens, se alastra por toda a abóbada celeste, dando razão, afinal, ao poeta míope, pois restam "arrebóis, de sangue". Diante desta ferocidade a que chegamos por meio do avanço tecnológico, que tem exposto nossa natureza de "onças disfarçadas" [lembremos que a Segunda Grande Guerra paira por toda a Invenção: "No armistício os cordeiros se suicidaram, / o mundo ia acabar, nasceu no mar / um cogumelo imenso, um cogumelo" (1952, p. 396), clara imagem da bomba atômica televisionada], o rapsodo conclui que é "bem melhor babar ternuras que / violências, escutar qualquer cantiga" (grifo).

Sobre a temática da música indígena e seus arredores, um intertexto determinante na Indíada limiana é o que se estabelece com cantos, lendas e costumes coligidos em Os Boróros Orientais: Orarimogodógue do Planalto Oriental de Mato Grosso (1942), profuso compêndio etnográfico sob a tutela dos missionários salesianos Antonio Colbacchini e Cesar Albisetti. Profusão esta amalgamada por Lima em quatro estrofes, na continuidade (e no completo deslocamento) daquela sobre as "Lisboas babeladas", "os domínios distantes me afogando, / cotovelado pelo Rei das quinas, / resgatado com fardos e tonéis, / descoberto de trajes e de galas."

Ou então em bororo me chamando.

— que venha o peixe ocogue! e o peixe veio

e outros peixes gerados com ixegui.

Quero dois paus para acender meu fogo,

a morada das almas me chamou,

bororo forte, linguagem de bororo.

Dentro dos jenipapos o ser grávido

subiu na árvore, fruto, irmã menor,

para flechar morada de assovios,

as águas se alargaram, a anta veio, 
então chegou a terra e se embebeu, formou um vale, o vale se fendeu.

Conheço plantas pra grudar memórias, boas embiras amarrando os cantos, resinas, cascas para funerais, para caçadas, cantos de pescar, ó filas de antas, taquarais, canastras, ruídos tristes, largados, desabados.

O fogo na penugem da montanha, o fogo sôbre o rio, sôbre a mata, nos limites da mata, roda as onças, urro em fogo das onças, onças indo com a montanha de fogo, mata em fogo, antas indo com o fogo, e o fogo indo. (1952, p. 57-58)

Logo se lê que este poeta, diferente do hagiógrafo de Anchieta, sabe que o índio imagina para muito além e aquém "dos musculos e das mungangas de guerra" (ainda que sua imaginação —ou sua ontologia— seja corpórea e bélica), e que ele compõe seu próprio "alimento musical”. Os versos "Conheço plantas pra grudar memórias, / boas embiras amarrando os cantos”, como já notara Lucia Sá (2000, p. 90), inspiram-se no uso indígena de certas plantas para auxílio ritualístico, uso que se estende desde o aprendizado do canto e sua memorização até a performance. ${ }^{16}$ Estas estrofes 13 a 16 do subpoema XXXII tocam com intensidade em temas caros da Invenção de Orfeu: a mágica potência da voz, “- que venha o peixe ocogue! e o peixe veio"; a maravilha e a violência da memória, sua precisão e sua volubilidade simultaneamente, sua inconstância vegetal concomitante à sua rigidez arbórea, talvez numa palavra, sua movença.

Na estrofe 16, lê-se uma reescritura (ou uma farsitura) do "Outro Canto Inicial da Caça" (Roia baregue paru) transcrito pelos missionários salesianos, cuja nona estrofe é assim traduzida: "O fogo vai no princípio da mata;

[16] Nas palavras de Colbacchini e Albisetti, lidas e recantadas por Lima: "é muito comum o uso supersticioso de plantas consideradas capazes de ajudar a inteligência para aprender e recordar os cantos e tornar forte a voz para cantá-los. Por ex.: para aprender a cantar é sufíciente carbonizar a raiz carnosa do jureu, um arbusto, e com o carvão sujar as orelhas. Para aprender e lembrar maravilhosamente os cantos e as lendas, basta mastigar as folhas de uma planta chamada baxe ennoddo-re-u, ou então introduzir no orifício do lobo auricular um galhinho do jowe e erubbo; para ter bela e vibrante a voz durante os cantos, engolem o suco das folhas do ruo poroddogeba ou senão do nabure e jorubbo." (1942, p. 361). 
no meio da mata; no limite da mata; por cima da mata" (1942, p. 386). A partir daí, Niraldo de Farias afirma que "o primitivismo de Jorge de Lima realiza-se [...] não só no plano temático, mas na própria dimensão lingüística da sua poesia que procura mimetizar discursos poéticos relegados pelo processo histórico" (2003, p. 98). É preciso acrescentar, neste caso, que o "primitivismo" do poeta não se restringe ao modo como Colbacchini-Albisetti traduzem o canto, mas busca na sonoridade original orari a insistência do fogo, do que faz arder, uruia, e por conseguinte, o seu "rythmo colossal”, calcado na extrema repetição e breves variações: "uruia koddure aibo parugi / uruia koddure aibo oiagi / uruia koddure aibo ottogi / uruia koddure aibo oiogi" (1942, p. 381). A estrofe limiana toma sua força da repetição extrema das palavras: "fogo", "montanha", "mata", "onças", "indo", a ponto da combinatória do último verso trazer apenas dois termos novos para a variação: "antas" e a conjunção "e", conclusiva do incêndio caçador: "e o fogo indo". A expressão "na penugem da montanha", por sua vez —ainda que possa reforçar a ideia da profanação causada pela interferência no canto sagrado, já subtraído de seu contexto, nu de sua eficácia ritualística ${ }^{17}$-, não se exterioriza como uma inserção de todo absurda, pois a montanha, que já foi gente como nós, diria Macunaíma, se veste ou se adorna com a mata. Para o ameríndio, a flora que a cobre é sua "'roupa" (CASTRO, 2013, p. 351), sua "penugem", sua túnica inconsútil (!?), ora em chamas.

Escavemos (ou saqueemos) um pouco mais, na direção da estrofe 14: "Dentro dos jenipapos o ser grávido / subiu na árvore, fruto, irmã menor", etc., onde lemos sem dúvida uma narrativa ameríndia, todavia insolitamente contada. O que se passa com esse Narrador? Estará mutilada sua memória, esta para a qual, logo a seguir, como a desculpar-se, ele afirma conhecer "plantas pra grudar"? Mais parece um papagaio que repete palavras aprendidas, sem consciência do sentido... (Mas quem pode afirmar que o papagaio não tem consciência do sentido, e que o humano tenha?) A estrofe 14 da Indíada fusiona pelo menos duas narrativas, sendo que a primeira é a lenda etiológica de um mé, folha pra fumar, assim como do milho, da resina kiddoguru, do algodão e do urucum: a lenda de Aturuaroddo, mulher que trazia nas costas uma sucuri (ou uma anaconda; ou até mesmo um dragão, segundo as

[17] Sobre este tipo de deslocamento, afirma Antonio Candido, tratando não exatamente do canto de caça, mas do fúnebre: "o roia kurireu, o 'canto grande' bororó, lido, ou ouvido de um informante nativo, perde o verdadeiro significado, pois não apenas foi feito para celebrar experiências coletivas, mas funciona em vista de uma dada situação, é executado no momento conveniente, requer uma recriação a cada execução, pelos cantores e bailarinos." (2006, p. 58). 
versões apresentadas por Colbacchini-Albisetti) que o marido havia capturado, e cujo sangue (a escorrer durante o carregamento; ou durante uma dança na qual ela não se havia protegido com uma folha no cinto, como as outras), penetrou-lhe:

Ixare areru meru-re, tu guiaru innoddu tabo, gi.

Então a mulher foi procurar comida, ela estando grávida assim mesmo, longe.

Ixare aregóddu-re bie i paru kae. Xare areddu akoe: ioguddu ba ruttu mo-

Então chegou de um genipapo ao pé. Então a mulher disse: Quem subide bettu-ré-boa kae i kegge? Ixare kuiaru-re joki- boe

rá até a fruta, por minha comida? Então a coisa que gravidou sobre, mako-re tadda i paru; akore: i muga, imi-re, $i$

falou dentro (da mulher) ao pé da planta; disse: minha mãe, eu, eu subirei

ruddu mode kae a ke-gge. [...]

até as frutas, por tua comida. [...]

(Colbacchini; AlbisetTi, 1942, p. 324)

Então a mulher tentou fugir, mas a serpente que havia saído dela para colher a fruta, alcançou-a e entrou novamente. Aturuaroddo contou o caso aos seus "irmãos maiores", que a acompanharam quando a saída do ventre para buscar o jenipapo se repetiu. Daí eles "correram também de sua irmã menor atrás" (1942, p. 325, grifo), e a mataram. Do lugar em que a lançaram ao fogo, brotaram o fumo e os outros produtos sagrados. No poema moderno, vicejam resíduos: a sua própria fragmentação ajuruana do discurso (de ayu'ru, em tupi, papagaio) reflete esta tentativa de uma tradução literal, linear, da lenda indígena no livro alheio; reflete a impossibilidade que radia o poético. A outra narrativa que o rapsodo da Invenção funde, na mesma estrofe, é a da inundação, ajuru ou caoticamente relatada. Na lenda orarimogodógue, Jokurugwa ou Meririporo, o único sobrevivente, é também o culpado pelo dilúvio, pois flechou a alma (ou espírito) Jakome amarelo. Ele avisou a todos, mas os outros não acreditaram:

Xare pobba-re tu maeddu boe e jameddu joki; koddire po-re kiegue

Então a agua se alargou cousas todas sobre; porisso a agua, as aves, baregue, boe e iameddu bitto. Mare xeu imeddu, ruddu-te tori as feras, os seres todos matou. Mas aquele homem, o qual subiu sobre o ki pobba ott-o dai-ure, ge kimore, xare koddu giii tori raixiiigo-re-u monte a agua diante, vivia ainda, porque foi do monte altíssimo ao kae (ma-re pa er-du-re gi-u tori karega) à sumidade (mas não o monte que nós vemos). (1942, p. 328) 
A "morada de assovios" a que o poema se refere metonimicamente é a aldeia para a qual o índio solitário retorna, após baixarem as águas por força de pedras quentes por ele lançadas. Assobiando em busca de outros sobreviventes, nenhum índio encontra, mas apenas uma cerva, com quem repovoa o mundo. "as águas se alargaram, a anta veio,". O rapsodo-papagaio modifica o animal totêmico para a anta, que também casa com homens em outras lendas indígenas. Antes de chegar à prole humana, no entanto, há geralmente uma série de nascimentos fabulosos, como no caso de Meririporo: entre os primeiros filhos, um veado com cabeça humana, que poderia até lembrar-nos obtusa e novamente da Grécia (e seus centauros), mas, por mais estranho que isso ainda possa soar, as lendas fusionadas na estrofe 14 estão bem mais próximas do outro mundo de formas - "anderen Formenwelt" (AUERBACH, 1946, p. 9) - que é a base oposta da literatura ocidental: o Velho Testamento hebraico. Do Gênesis: Eva, a serpente e o fruto (conexão obscura com Aturuaroddo); Noé e o dilúvio (conexão algo mais transparente com Meririporo). Invenção de Orfeu, que palimpcestua ${ }^{18}$ estes dois mundos (e seus desdobramentos romanos, medievais, renascentistas, barrocos...), com sempiterna inclinação para o lado obscuro e esfíngico, insere ou seduz também, na dança dialética da negação-amplificação das "escritas [e das oralidades] primordiais" (Neghme ECHeVeRRía, 1978, p. 31, alterada), a mitologia ou cosmognosia ameríndia, como um terceiro outro a ser cantado e deformado — para que se imite devidamente a confusa História-. A obra propõe, deste modo, uma trialética para a nossa mimese? O relativo, o absoluto e o uno relacional.

O contato do poema limiano com os textos anteriores do palimpsesto é dos mais complexos (plagiário, panegírico, basto, devorador, assassino). A necessidade de apagar o texto-outro e escrever sobre ele, rasurá-lo, aponta para a negação, a negaça, mas simultaneamente indica a permanência (e a amplificação) daquele outro, a impossibilidade de simplesmente esquecê-lo, renegá-lo; isto é: a contingência de —eternamente ou enquanto for possível — ouvi-lo, lê-lo; mediatamente reescrevê-lo; relê-lo em seu próprio texto. Este roteiro serve tanto para o autopalimpsesto [que lida forçosamente com o "serpentário de erros" (1952, p. 32) históricos do aedo — desde sempre uma voz entre o sagrado e o político—, pois o que 
lemos é sua "Biografia Épica", o subtítulo fulcral grafado em marginália], quanto serve para o alterpalimpsesto. Uma alteridade violada e violadora, em "summa vingança".

\section{UMA INFENSA GEOGRAFIA}

É preciso ver quem é o anthropophago. Dentro do indio estarão o português e o preto? Ou os dois primeiros estarão dentro do ultimo? Ou terá sido o português quem comeu os dois anthropophagos? Parece que as raças se entredevoram. Que se estão entredevorando ainda.

“Todos cantam sua terra..." (1929)

agora uns pobres nus sem escamas e sem sangue,

já não conseguem mais alongar-se em cardumes, esquecem-se do oceano e da vida que era o oceano agora morto, sim, como um ser contemporâneo, sem pureza xavante, irmão desse céu inane, igual a um mar sem onda, um bronco e escuro oceano

Canto VI, “Canto da Desaparição”, VII (1952)

Retomando a paráfrase de Roger Bastide, poderia afirmar que a poesia de Jorge de Lima procura na ausência do índio o que subsiste ainda de índio, "em piedosa e ao mesmo tempo desesperada peregrinação"?

Tal qual na questão africana, o que aparece em contornos extremamente problemáticos na prosa ensaística de Lima ressurge problematizado em sua poesia, mormente na Invenção, escritura-para-a-morte (iniciática). A "complexidade no tratamento da voz narrativa” (SÁ, 2000, p. 91) na Indíada é uma característica-chave neste sentido, pois a própria assunção negativa da voz lusitana/ocidental/branca — "nós os complexos, nós os pioneiros, / nós os devastadores e assassinos"- vai além de mera retórica engajada, dimensionando-se de fato no diálogo com a obra anterior do auctor "degradado" (está em jogo sua responsabilidade histórica), contrapondo-se assim violentamente à voz do índio, que ele (auctor, rapsodo, pantomimo, biógrafo épico, aedo, esta simples tentativa de nomeá-lo é frutífera e contraditória) também assume, inclusive na $1^{\text {a }}$ pessoa do singular, como no já citado "Sobretudo eu escravo do homem branco". Mas só é possível afirmar que na prosa está a ideologia e no poema a contraideologia, se ficar bem matizada sua interpenetração, pois tanto na prosa encontram-se pinceladas, talvez demasiado opacas, que ultrapassam a "mera" ideologia, quanto e sobretudo no poema 
se pode visualizar um emaranhado de tensões quase indescritível: a repetição de trechos de Anchieta que menosprezam a música indígena coabita com a afirmação de que "qualquer cantiga" é melhor que as violências do branco (entre estas deve-se listar, com destaque, a invasão/violação da terra-mãe-alheia) e coabita ademais com a nevrálgica apropriação intertextual de um canto de caça —através de seu registro por obra de missionários modernos (!)—; ao mesmo tempo, a sede do estrangeiro por descrever/expor/compor extraindo o sangue da cultura indígena, para logo depois catalogá-lo na estante do "folclore", é deveras ironizada e criticada pelo mesmo fragmento XXXII, pois esse contato, sublimado em tais produções científicas ${ }^{19}$ ou artísticas, é afinal de contas também responsável pelo genocídio - “Já não estais, timbiras, já não sois."-, pelo medo — "É preciso andar sertões pra encontrar-vos, / verter íntimos sangues, correr matos, / braúnas, umbusais para encontrar-vos.”-, pelas doenças, pela degeneração, pela fome - “Já não sois belos como nos Caminhas, / e sois enfermos e não sois tão nus. [...] Êles que jantam? Pratos? Pesadumes? [...] escorbutos de fomes escondidas"- (1952, p. 54-67).

As espessas trevas [caligo grandis], que pairaram sobre o oceano durante a santa viagem, avançam para o continente, onde outrora "havia / uma clara geografia". A Ilha desafortunada, infelicitada, Atlântida vencida, conhece a Revelação —o Apocalipse - por mão de "naos alertas / de vária mastreação". Há iluminações e rodopios intermitentes nestas trevas: são os trovões e furacões de Tupã-Deus-Zeus. Mas nem desesperado, nem piedoso está o Narrador [outro de seus (im)possíveis nomes], pois seu canto se move propriamente "no elemento sombrio da continuidade, da indiscernibilidade e da irreversibilidade" (CASTRO, 2013, p. 294). O desdobramento ou a deriva incessante de sua posição histórica forja o Canto escritural, capaz de numa página, com voz de índio-Macunaíma, pedir paz: "Moremos êsse dôce papiri, / sem maliciando ações, sem cancerando / [...] sem preparos de flechas e de chumbos". E na seguinte, com a voz do branco ou do mestiço, requerer vingança contra si mesmo: "Podeis frechar-nos índios atuais, / e mesmo detestar-nos, devorar-nos".

[19] Claro e constante contrassenso é desprezar, "desbaratar" os viventes para depois fetichizar os artefatos: "34 flechas, 2 arcos, 1 vara de pescar e outros pequenos objetos", por exemplo, tornam-se "material raro" (IHERING; IHERING, 1911, p. 6 apud FERREIRA, 2009, p. 71) quando se ordena, cientificamente, a extinção de seus criadores. "Caveiras em museus; Pedro Segundo / vendo estantes, fantástico barbaças! / E ao lado as prateleiras com uma fauna / de peixes empalhados, irmãos gêmeos / de teu anfíbio índio mergulhado, / dissolvido nos rios e nas febres. // E sua muda fala com os das águas / que o rei jamais entende, fala sêca / conservada nos álcoois ou moquém / de sombra nas malocas devastadas / pelos filhos do rei. Catalogados / uns fiapos, umas tangas, uns chocalhos." (LIMA, 1952, p. 59-60). 
Mesticismo: autoflagelação, transcendência tética, libídia. "O azorrague não deu resultado. Literatura tambem é sacrificio." (LimA, 1934a, p. 159). Na "carnifágia" (1952, p. 64, 65, 189, 211) da Invenção de Orfeu, a operação canibal em que devém o "par matador-vítima" é também uma face do ato sexual que propaga o "Amado estupro". O palimpsesto faz ecoar o incesto. "Filho, filha, mútua / pendência em tudo, a mesma arena e cama." "ia iedaga mague, imana mague, ia ituie mague, ia imuga mague". Violentar os próprios avós, os próprios irmãos, a(s) própria(s) raça(s). Devorar o índio, isto é, uma parte de si mesmo, para a continuidade do seu corpo por meio da reinvenção dessa memória devastada pelo outro - outra parte de si-; e para invocá-los, ao índio e aos outros -a própria constituição de si mesmo—, a fim de "redevorar" (CAMPOS, 1981, p. 24) essa carne de vozes e textos.

A Ilha remanesce infundada.

Nêsse regime de baraço e cutelo viveu o SPI [Serviço de Proteção ao Índio] muitos anos. A fertilidade de sua cruenta história registra até crucificação, os castigos físicos eram considerados fato natural nos Postos Indígenas.

[...] a legislação que proíbe a conjunção carnal de brancos com índios já não era obedecida e dezenas de jovens "caboclas" foram infelicitadas por funcionários, algumas delas dentro da própria repartição.

RELATÓRIo Figueiredo (1967, p. 4913-4914) I

DANIEL GLAYDSON RIBEIRO - Graduado em Letras na Universidade Estadual Vale do Acaraú, Sobral, Ceará. Mestre em Língua Espanhola e Literaturas Espanhola e Hispano-americana e doutorando em Teoria Literária e Literatura Comparada na Universidade de São Paulo. Bolsista CNPq. Poeta e ator. dgribeiro@usp.br 


\section{REFERÊNCIAS}

ALVES, Hélio J. S. "A Memória Épica Portuguesa de Jorge de Lima: novos elementos no centenário do poeta”. In: Vértice. II série. no. 57. p. 119-124. Lisboa, nov-dez, 1993.

ANDRADE, Mário de. Música de feitiçaria no Brasil. org. Oneyda Alvarenga. São Paulo: Livraria Martin Editôra, 1963.

ANÔNIMO. Navigatio Sancti Brendani Abbatis: transcription du manuscrit d'Alençon, Codex 14, fo 1-r à 11-v. ed. Guy Vincent. Alençon: ca. 900. <http://www. hs-augsburg.de/ harsch/Chronologia/Lspost10/Brendanus/bre_navi.html> AUERBACH, Erich. Mimesis: Dargestellte Wirklichkeit in der abendländischen Literatur. Bern: Francke Verlag, 1946.

BANDEIRA, Antônio Rangel. Jorge de Lima: o roteiro de uma contradição. Rio de Janeiro: Livraria São José, 1959.

BASTIDE, Roger. Poetas do Brasil. São Paulo: Editora da Universidade de São Paulo; Duas Cidades, 1997.

BECKETT, Samuel. Nohow On. London: John Calder, 1989.

BILAC, Olavo; PASSOS, Guimarães. Tratado de versificação. Rio de Janeiro: Typ. da Livraria Francisco Alves, 1905.

CAMINHA, Pero Vaz de. A Carta. ed. Jaime Cortesão. Rio de Janeiro: Livros de Portugal, 1943.

CAMPOS, Haroldo de. "Da razão antropofágica: a Europa sob o signo da devoração". In: Colóquio / Letras. n. 62. p. 10-25. Lisboa: Calouste Gulbenkian, 1981.

CANDIDO, Antonio. Literatura e sociedade. 9. ed. rev. Rio de Janeiro: Ouro sobre Azul, 2006.

CASSIRER, Ernst. Essay on man: an introduction to a philosophy of human culture. New Haven: Yale University Press, 1944.

CASTRO, Eduardo Viveiros de. A inconstância da alma selvagem e outros ensaios de antropologia. 5. ed. São Paulo: Cosac Naify, 2013. 
COLBACCHINI, P. Antonio; ALBISETTI, P. Cesar. Os boróros orientais: orarimogodógue do planalto oriental de Mato Grosso. São Paulo: Companhia Editora Nacional, 1942.

DIAS, A. Gonçalves. Segundos Cantos e Sextilhas de Frei Antão. Rio de Janeiro: Typograpia Classica de José Ferreira Monteiro, 1848.

EULALIO, Alexandre. "A obra e os andaimes". In: Folha de São Paulo - Folhetim. p. 6-7. São Paulo, 20 de novembro de 1983.

FARIAS, José Niraldo de. O surrealismo na poesia de Jorge de Lima. Porto Alegre: EDIPUCRS, 2003.

FAUSTINO, Mário. "Revendo Jorge de Lima”. In: De Anchieta aos concretos. org. Maria Eugenia Boaventura. São Paulo: Companhia das Letras, 2003.

FERREIRA, Lúcio Menezes de. "Diálogos da arqueologia sul-americana: Hermann von Ihering, o Museu Paulista e os museus argentinos no final do século XIX e início do XX”. In: Revista do Museu de Arqueologia e Etnologia. n. 19. pp. 63-78. São Paulo, 2009.

FONSECA, Simões da; RIBEIRO, João. Novo Diccionario Encyclopedico Illustrado da Lingua Portugueza. Rio de Janeiro: Garnier, 1926.

FRANCO, Afonso Arinos de Mello. O indio brasileiro e a revolução francesa: as origens brasileiras da theoria da bondade natural. Rio: José Olympio, 1937.

HUME, David. História natural da religião. trad. Jaimir Conte. São Paulo: Editora Unesp, 2005.

. An enquiry concerning human understanding. New York:

Collier \& Son, 1910

. The natural history of religion. London: A. and H. Bradlaugh Bonner, 1889.

IHERING, Hermann von. "A Civilização Pré-História no Brasil Meridional”. In: Revista do Museu Paulista. n. 1. p. 33-159. São Paulo, 1895.

IHERING, Hermann von; IHERING, Rodolfo von. "O Museu Paulista nos anos de 1906 a 1909". In: Revista do Museu Paulista. n. 8. p. 1-22. São Paulo, 1911. 
JACOBBI, Ruggero. “Introduzione”. In: LIMA, Jorge de. Invenzione di Orfeo. trad. Ruggero Jacobbi. Roma: Abete, 1982.

LANCIANI, Giulia. "O maravilhoso como desvio entre sistemas culturais". In: A língua portuguesa em viagem: actas do Colóquio Comemorativo do Cinquentenário do Leitorado de Português da Universidade de Zurique. ed. Marília Mendes. Frankfurt am Main: Teo Ferrer de Mesquita, 2003.

LERY, lean de. Histoire d'un voyage faict en la terre du Bresil, autrement dite Amerique. Geneve: Antoine Chuppin, 1580.

LÉRY, Jean de. Viagem à Terra do Brasil. ed. Paul Gaffarel. trad. Sérgio Milliet. São Paulo: Livraria Martins, 1941.

LIMA, Jorge de. "À margem de Euclides”. In: TERESA revista de Literatura Brasileira. n. 3. p. 179-182. São Paulo: Ed. 34, 2002.

Obra completa. org. Afrânio Coutinho. Rio de Janeiro: Aguilar, 1958. Invenção de Orfeu. Rio de Janeiro: Livros de Portugal, 1952. "O índio brasileiro". In: Jornal A Manhã. dir. Cassiano Ricardo. p. 4 e 8. Rio de Janeiro, 10 de março de 1942.

Obra poética. org. Otto Maria Carpeaux. Rio de Janeiro: Getúlio Costa, 1950. Rassenbildung und rassenpolitik in Brasilien. Leipzig: Adolf Klein, 1934. Anchieta. Rio de Janeiro: Civilisação Brasileira, 1934a. Dois ensaios. Maceió: Casa Ramalho, 1929.

LOPES, Rodolfo. "Introdução”. In: PLATÃo. Timeu-Crítias. Coimbra: Simões \& Linhares, 2011.

MONTAIGNE, Michel de. Essais: texte original de 1580 avec les variantes des éditions de 1582 et 1587. ed. Dezeimeris \& Barckhausen. Bordeaux: Féret et Fils, 1870.

NEGHME ECHEVERRÍA, Lidia. "Algumas orientação poéticas em Invenção de Orfeu”. In: Colóquio / Letras. n. 41. p. 26-35. Lisboa: Calouste Gulbenkian, 1978. 
ROSA, Guimarães. Ficção completa. Rio de Janeiro: Nova Aguilar, 1994.

RUGENDAS, Maurice. Voyage pittoresque dans le Bresil. trad. Mr. de Golbery. Paris: Engelmann \& Cie, 1853.

SÁ, Lúcia. “Invenção de Orfeu e o palimpsesto indígena”. In: Luso-Brazilian Review, vol. 37, no. 1 (Summer), pp. 83-92. Madison: University of Wisconsin Press, 2000.

SELIGMANN-SILVA, Márcio. O local da diferença: ensaios sobre memória, arte, literatura e tradução. São Paulo: Ed. 34, 2005.

SOUZA, Gabriel Soares de. Tratado descriptivo do Brazil em 1587: edição castigada pelo estudo e exame de muitos codices manuscriptos existentes no Brazil, em Portugal, Hespanha e França... por Francisco Adolpho de Varnhagen. Rio de Janeiro: Laemmert, 1851.

\section{DOCUMENTOS}

Arquivo Museu de Literatura Brasileira, Fundação Casa de Rui Barbosa - AMLBFCRB. Acervo Jorge de Lima. Álbum de recortes de periódicos nํ20, p. 97.

Arquivo Instituto de Estudos Brasileiros - IEB-USP. Fundo Mário de Andrade. Série Manuscritos. MA-MMA 032.

Arquivo do Museu do Índio. Relatório Figueiredo, Ministério do Interior, 1967. p. 4913-4914. 
